\title{
Evaluation of Aspergillus Galactomannan Lateral Flow Assay on Serum and Bronchoalveolar Lavage Specimens - Preliminary Results
}

\section{Evaluacija imunokromatografskog testa za otkrivanje galaktomanana Aspergillus spp. u uzorcima seruma i bronhoalveolarnih lavata - preliminarni rezultati}

Gabrijela Perše ${ }^{1}$, Marija Jandrlićc ${ }^{1}$, Violeta Rezo Vranješ', Sanja Pleško ${ }^{1}$, Ivana Marekovićc ${ }^{1,2}$

${ }^{1}$ Department of Clinical and Molecular Microbiology, University Hospital Centre Zagreb, Zagreb, Croatia

${ }^{2}$ Medical Microbiology Department, School of Medicine, University of Zagreb, Zagreb, Croatia

\author{
Keywords: \\ galactomannan \\ ELISA \\ serum \\ bronchoalveolar lavage \\ lateral flow assay \\ Ključne riječi: \\ galaktomanan \\ ELISA \\ serum \\ bronhoalveolarni lavat \\ imunokromatografskitest
}

Primljeno: 20-01-2021

Received: 20-01-2021

Prihvaćeno: 01-03-2021

Accepted: 01-03-2021

$\triangle$ Corresponding author: Gabrijela Perše

Department of Clinical and Molecular Microbiology

University Hospital Centre Zagreb

Kišpaticeva 12, 10000 , Zagreb, Croatia

Phone: +385 981356541

e-mail: gabi.perse@gmail.com

\begin{abstract}
Background: Detection of biomarkers, such as galactomannan (GM), has proven to be of great significance in early recognition of invasive aspergillosis (IA). The aim of our study was to evaluate the lateral flow assay (LFA) for the detection of GM on serum and bronchoalveolar lavage (BAL) samples previously proven positive by enzyme-linked immunosorbent assay (ELISA).
\end{abstract}

Methods: The study was performed on serum and BAL samples obtained from patients with suspected IA in the period from February 2019 to January 2020, which were previously GM positive by ELISA (Platelia Aspergillus Ag, Biorad, Hercules, USA). Samples were then tested by LFA (Aspergillus Galactomannan LFA, IMMY, Oklahoma, USA) with test line intensity visually read as $1+, 2+, 3+$, or $4+$.

Results: A total of 45 GM ELISA positive serum and/or BAL samples were obtained from 41 patients; 25 (55.6\%) were BAL and 20 (44.4\%) serum samples. LFA showed a positive result in 39 out of 45 (86.7\%) GM ELISA positive samples; $22 / 25$ (88.0\%) BAL samples and 17/20 (85.0\%) serum samples tested positive. In BAL samples, low intensity test line of $1+$ was significantly more frequent in GM ELISA positive samples with optical density index (ODI) $<1.0$ $(p=0.0002)$. Three serum samples with high GM ELISA ODI (>4.0) had low intensity line of $1+$ when tested with LFA.

Conclusions: Results obtained by LFA are comparable to GM ELISA. Since low intensity lines were found in serum samples with high ODI, this potentially makes BAL a superior sample for LFA, at least when visual and not automated reading is done.

\section{Sažetak}

Uvod: Određivanje galaktomanana (GM) igra značajnu ulogu u ranom otkrivanju invazivne aspergiloze (IA). Cilj je ovog istraživanja bila evaluacija imunokromatografskog testa (LFA) za određivanje GM u uzorcima seruma i bronhoalveolarnih lavata (BAL) s pozitivnim rezultatom koji su utvrđeni prethodno napravljenom ELISA metodom.

Metode: Istraživanje je napravljeno na uzorcima seruma i BAL-a pacijenata sa sumnjom na IA prikupljenim u razdoblju od veljače 2019. do siječnja 2020. godine. Uzorci s pozitivnim rezultatom utvrđenim ELISA metodom (Platelia Aspergillus Ag, Biorad, Hercules, USA) testirani su s LFA (Aspergillus Galactomannan LFA, IMMY, Norman, Oklahoma, USA) s vizualnim očitavanjem testne linije u rasponu 1+, 2+, 3+, ili 4+.

Rezultati: 0d 41 bolesnika dobiveno je 45 pozitivnih uzoraka seruma i/ili BAL-a testiranih GM ELISA metodom; 25 (55.6\%) uzoraka BAL-a i 20 (44.4\%) uzoraka seruma. LFA je pokazao pozitivni rezultat kod 39 od 45 (86.7\%) uzoraka pozitivnih GM ELISA metodom; 22/25 (88.0\%) uzoraka BAL-a i 17/20 (85.0\%) uzoraka seruma. Kod uzoraka BAL-a, testna linija slabog intenziteta 1+ bila je značajno češća kod pozitivnih uzoraka testiranih GM ELISA metodom s ODI < 1.0 ( $p=0.0002)$. Tri uzorka seruma s visokim ODI (>4.0) imala su pri testiranju s LFA testnu liniju slabog intenziteta $1+$.

Zaključak: Rezultati dobiveni s LFA usporedivi su s GM ELISA metodom. S obzirom da su testne linije niskog intenziteta utvrđene u uzorcima seruma s visokim ODI, uzorci BAL-a su potencijalno pogodniji uzorci za LFA, barem kad se radi o vizualnom, a ne automatiziranom očitavanju testa. 


\section{Introduction}

Aspergillus species is a diverse group of saprophytic and ubiquitous airborne fungi predominantly found in soil and on decaying vegetatation ${ }^{[1,2]}$. Basically, everyone during their lifetime will at some point inhale Aspergillus spores, but adequate immune respiratory tract defences such as mucociliary clearance, phagocytosis by alveolar macrophages, and/or neutrophils prevents localized colonization and further damage ${ }^{[3]}$. Aspergillus infection can exhibit a wide range of clinical presentations, but the most severe form of disease is invasive aspergillosis (IA) with dissemination to other organs, most commonly, the brain and the kidneys ${ }^{[1]}$.

Unfortunately, due to the expanding population of immunocompromised patients, the incidence of IA is increasing. Globally, it is estimated that there are over 300,000 cases of IA diagnosed annually, with mortality rate ranging from 30 to $80 \%^{[4,5]}$. The most significant risk factors include several immunosuppressive conditions such as prolonged neutropenia (generally $>7$ days), T cell defects, haematological malignancies with or without stem cell transplantation, acquired immunodeficiency syndrome (AIDS), chronic granulomatous disease, solid organ transplantation (SOT), and prolonged immunomodulatory therapy ${ }^{[6,7]}$.

Regardless of these risk factors for developing IA, this condition should also be considered in any critically ill patient, especially those with protracted hospitalization. IA is increasingly encountered in intensive care unit (ICU) environment even in non-immunocompromised patients, but with certain chronic comorbidities, such as chronic obstructive pulmonary disease, decompensated liver disease or cirrhosis, diabetes mellitus, autoimmune disorders and prior viral or bacterial pneumonia ${ }^{[8,9]}$.

There are two significant viral diseases which particularly facilitate Aspergillus invasion and have been recognized as important entities by medical mycology societies: influenza-associated pulmonary aspergillosis (IAPA) and COVID-19-associated pulmonary aspergillosis (CAPA). Both respiratory viruses cause impairment of the airway epithelium, thus enabling damage to the lung tissue by numerous fungal pathogens, including Aspergillus. Moreover, viral infections themselves cause immune system malfunction which can be further debilitated by corticosteroids and other immunomodulatory drugs used in treatment of such conditions. In patients with COVID-19 pneumonia, especially severe cases, a decline in T-cell populations is observed ${ }^{[10]}$. IA is especially emerging in influenza patients who are being admitted to the intensive care unit (ICU). The median time between the viral pneumonia diagnosis and aspergillosis development was 5 days for IAPA and 10 days for CAPA, respectively ${ }^{[11,12]}$.
A recent Dutch-Belgian multicentre study over seven influenza seasons in seven institutes showed that the 90-day mortality rate for ICU patients with IAPA was almost double that of ICU influenza patients without IAPA ( $51 \%$ vs. $28 \%)^{[11]}$. It seems that the same trend applies to CAPA, whereas higher 30-day mortality was observed in patients with CAPA than in patients without Aspergillus superinfection (44\% vs $19 \%)^{[10]}$.

To this day significant efforts have been made to improve diagnostic algorithms for IA. Conventional methods based on culture, microscopic examination of primary sterile specimens and bronchoalveolar lavage (BAL) as well as histopathological demonstration of tissue invasion through different stains (Calcofluor White ${ }^{\text {rix }}$, Gomori's methenamine silver stain, periodic acid-Schiff) are still the golden standard for diagnosis of proven IA. However, these conventional methods have several serious drawbacks including the necessity of obtaining the invasive sample, low sensitivity and long turnaround time ${ }^{[13]}$. There are novel, non-culture based molecular techniques, such as PCR, but the downside is their cost and utility, especially in small, low resource laboratories. On the other hand, detection of biomarkers, such as galactomannan (GM) has proven to be of great value in early recognition of IA. ELISA method for detecting GM has been commercially available for more than two decades now, but its use is limited with obstacles such as high cost and long turnaround time. Namely, ELISA method requires batching of samples resulting in suboptimal reporting time with possible questionable impact on patient management. Lateral flow assay (LFA) is now an available alternative for single sample testing, especially in low-volume settings, with the results available in 30 minutes ${ }^{[14]}$.

The aim of our study was to evaluate the LFA test for detection of GM on serum and BAL samples previously positive by ELISA method.

\section{Methods}

The study was performed on serum and BAL samples obtained from patients with suspected IA in the period from February 2019 to January 2020 that previously tested GM positive by ELISA method (Platelia Aspergillus Ag, Biorad, Hercules, USA). GM results in ELISA method are reported as optical density index (ODI) and according to the manufacturer's instructions samples with ODI $\geq 0.5$ were considered positive.

Samples with positive ELISA result were then tested by LFA (Aspergillus Galactomannan LFA, IMMY, Norman, Oklahoma, USA). Both sera and BAL samples $(300 \mu \mathrm{L})$ underwent pre-treatment procedure to allow adequate binding of the detecting antibodies; 
they were vortexed, heated to $120^{\circ} \mathrm{C}$ in order to denature the immunoglobulins and any other potentially interfering proteins, and centrifuged, following the manufacturer's instructions. An aliquot was transferred to a second tube and mixed with a running buffer. Test strips were then inserted into $80 \mu \mathrm{L}$ of attained supernatant and the results were read after 30 minutes. The presence of two lines (control and test line), regardless of their intensity, was interpreted as a positive result. Negative result forms only one line (control line). If the control line fails to develop, the test is deemed invalid. The intensity of the test line was visually read using the reading card included in the kit and ranked according to the intensity scale defined by the manufacturer from $1+$ to $4+$ (Figure 1).

Statistical analysis included descriptive frequency tables and Fisher's exact test. A P-value less than 0.05 was considered significant.

Figure 1. Lateral flow assay (LFA) Showing positive ReSULT WITH TEST LINE INTENSITY $3+$

SLIKA 1. IMUNOKROMATOGRAFSKI TEST (LFA) S POZITIVNIM REZULTATOM I INTENZITETOM TESTNE LINIJE $3+$

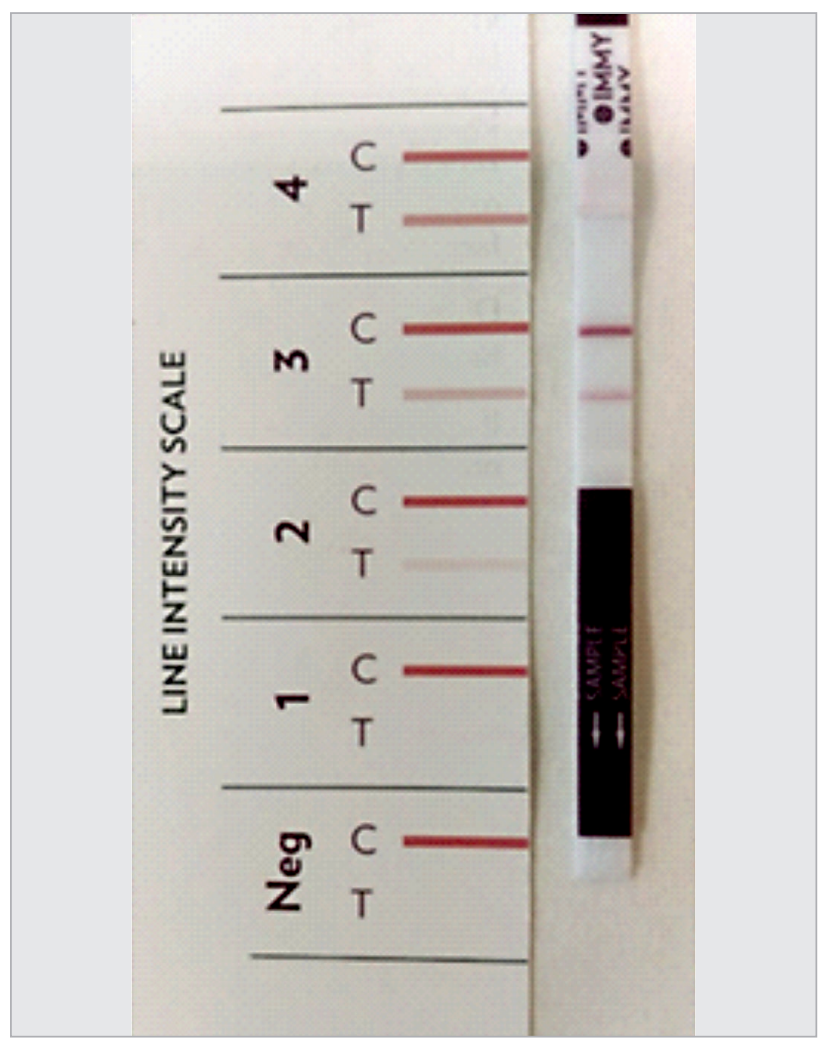

Results

A total of 41 patients, 29 males and 12 females, with positive GM result in serum and/or BAL sample obtained by ELISA method were included in the study. The median age was 53.1 years (range 2-77). A total of 45 GM ELISA positive serum and/or BAL samples were obtained from 41 patients included in the study. Out of a total of 45 samples, 25 (55.6\%) were BAL and $20(44.4 \%)$ were serum samples. In four patients two samples were obtained - in one patient two serum samples, in other patient two BAL samples and in two patients both, serum and BAL sample. The most common underlying disease in the patients included in the study was haematological malignancy $(\mathrm{n}=17,41.5 \%)$ followed by solid organ neoplasms $(n=6,14.6 \%)$ and solid organ transplantation $(\mathrm{n}=3,7.3 \%)$ (Table 1$)$.

Table 1. Demographic Data AND UNDERLYing Diseases of PATIENTS WITH SUSPECTED INVASIVE ASPERGILLOSIS AND POSITIVE GALACTOMANNAN RESULT OBTAINED BY ELISA METHOD $(\mathrm{N}=45)$ TABLICA 1. DEMOGRAFSKI PODACI I OSNOVNA BOLEST PACIJENATA SA SUSPEKTNOM INVAZIVNOM ASPERGILOZOM I POZITIVNIM REZULTATOM GALAKTOMANANA DOBIVENIM ELISA METODOM $(\mathrm{N}=45)$

\begin{tabular}{|l|l|}
\hline Gender $(\mathrm{m} / \mathrm{f})$ & $29 / 12$ \\
\hline Median age (range) & $53.1(2-77)$ \\
\hline Underlying disease & $\mathrm{n}(\%)$ \\
\hline Hematologic malignancy & $17(41.5 \%)$ \\
\hline Solid organ neoplasm & $6(14.6 \%)$ \\
\hline Solid organ transplantation & $3(7.3 \%)$ \\
\hline Other & $15(36.6 \%)$ \\
\hline
\end{tabular}

LFA displayed a positive result in 39 out of 45 (86.7\%) GM ELISA positive samples. Among 39 LFA positive samples, $22 / 25(88.0 \%)$ BAL samples and $17 / 20(85.0 \%)$ serum samples tested positive. In more than half of LFA positive samples $(20 / 39,51.3 \%)$, the test line intensity was $1+$. In BAL samples, low intensity test line of $1+$ was significantly more frequent in GM ELISA positive samples with ODI $<1.0(7 / 7,100$ $\%)$ than with ODI $\geq 1.0(2 / 15,13.3 \%)(p=0.0002)$. In serum samples low intensity test line of $1+$ was not significantly more frequent in GM ELISA positive samples with ODI $<1.0(3 / 4,75 \%)$ than with ODI $\geq 1.0$ $(8 / 13,61.5 \%)(p=1.0)$. Moreover, three serum samples with high GM ELISA ODI ( $>4.0)$ had low intensity line of $1+$ when tested with LFA.

Out of six LFA negative samples, sera and BAL were equally represented $(n=3)$ and the majority of these samples $(5 / 6,83.3 \%)$ had ODI $<1.0$ (Table 2).

\section{Discussion}

Detection of fungal biomarkers is widely used diagnostic tool for IA. GM is a polysaccharide component of Aspergillus spp. cell wall and is released during invasive fungal infections. It can be successfully detected in patients' serum and BAL samples and is more 
TABLE 2. COMPARISON OF GALACTOMANNAN IMMUNOENZYMATIC ASSAY (ELISA) AND LATERAL FLOW ASSAY (LFA) ON SERUM (N=2O) AND BRONCHOALVEOLAR LAVAGE (BAL, N=25) SPECIMENS

TABlicA 2. UsPoredbA REZUltatA IMUNOENZIMSKe METOdE (ELISA) I IMUNOKROMATOGRAFSKOG TESTA (LFA) ZA OTKRIVANJE GALAKTOMANANA U UZORCIMA SERUMA $(\mathrm{N}=20)$ I BRONHOALVEOLARNIH LAVATA (BAL, N=25)

\begin{tabular}{|c|c|c|c|c|c|c|c|}
\hline \multirow[t]{2}{*}{ Lateral flow assay result } & \multicolumn{4}{|c|}{ Lateral flow assay test line intensity } & \multicolumn{3}{|c|}{ ELISA OD value } \\
\hline & $1+$ & $2+$ & $3+$ & $4+$ & $<1.0$ & $1.0-5.0$ & $>5.0$ \\
\hline Positive serum samples $(\mathrm{N}=17)$ & 11 & 4 & 1 & 1 & 4 & 10 & 3 \\
\hline Negative serum samples $(\mathrm{N}=3)$ & $\mathrm{N} / \mathrm{A}$ & $\mathrm{N} / \mathrm{A}$ & $\mathrm{N} / \mathrm{A}$ & $\mathrm{N} / \mathrm{A}$ & 3 & 0 & 0 \\
\hline Positive BAL samples $(\mathrm{N}=22)$ & 9 & 7 & 3 & 3 & 7 & 6 & 9 \\
\hline Negative BAL samples $(\mathrm{N}=3)$ & $\mathrm{N} / \mathrm{A}$ & $\mathrm{N} / \mathrm{A}$ & $\mathrm{N} / \mathrm{A}$ & $\mathrm{N} / \mathrm{A}$ & 2 & 1 & 0 \\
\hline
\end{tabular}

$\mathrm{OD}=$ optical density $\mathrm{N} / \mathrm{A}=$ not applicable; $\mathrm{BAL}=$ bronchoalveolar lavage

sensitive than culture for diagnosis of IA. Presence of GM in serum can be detectable several days (usually 5 to 8 ) before clinical signs, radiological evidence or positive culture ${ }^{[6,15]}$. Furthermore, presence of GM in BAL specimens precedes its appearance in serum as the lungs are the primarily affected organ ${ }^{[16]}$.

In tertiary care settings, GM was so far commonly detected by commercial ELISA assay that has already been extensively evaluated by numerous studies. A meta-analysis of the Cochrane database showed a sensitivity and specificity of, respectively, $82 \%$ and $81 \%$ for a cut-off value of $0.5^{[17]}$. Sensitivity of serum GM testing is significantly lower in non-neutropenic versus neutropenic patients. In serum samples an ODI cut-off of 0.5 results in high sensitivity in haematological patients in the absence of mould-active prophylaxis. GM detection in BAL specimens has higher sensitivity with evidence that ODI of $0.5-1.0$ has decreased predictive values compared with results of $>1.0^{[13,18,19]}$.

Recently available LFA (Aspergillus Galactomannan LFA, IMMY, Norman, Oklahoma, USA) represents further improvement in mycology providing low cost, rapid test results and no further need for specimen batching, which is usually the case with ELISA method. LFA is a qualitative and quantitative immunochromatographic test system which also enables detection of Aspergillus spp. GM in serum and BAL samples. GM-specific antibodies conjugated to colloidal nano-gold bind to GM, if it is present in the sample, and the antibody-antigen complex migrates up the strip until it is captured by the GM-specific antibodies in the test line ${ }^{[14]}$.

The LFA uses a proprietary mix of two different mAb's: the ME-A5 human immunoglobulin G (IgG) monoclonal, and an undisclosed proprietary $\mathrm{mAb}$ with an unknown target. The ME-A5 mAb targets similar or identical epitope as the EB-A2 rat $\mathrm{mAb}$ used in the Platelia ${ }^{\mathrm{TM}}$ GM ELISA. Most studies to date have published performance of the LFA in patients with haematological malignancies, where the assay showed very good to excellent discriminatory power for IA in serum and BAL samples, with performances similar to GM ELISA. To this day, studies have focused mainly on the performance of the LFA when testing respiratory samples (e.g., BAL), generating sensitivity and specificity of 83 to $92 \%$ and 91 to $92 \%$, respectively ${ }^{[20,21,22]}$. The first evaluation of the LFA to assist in the diagnosis of IA when testing serum samples showed sensitivity and specificity of $96.9 \%$ and $98 \%$, respectively ${ }^{[23]}$. Larger multicentre studies are needed to investigate performance of the LFA diagnosis of IA in other patient groups who are increasingly reported at risk for IA, such as SOT recipients or patients in the ICU ${ }^{[21,22]}$.

Galactomannan is not strictly specific to Aspergillus spp. and can be secreted by other fungal pathogens (Histoplasma, Alternaria, Fusarium, and Penicillium), which may lead to false-positive results. However, it has very satisfactory negative predictive value (NPV) of $>90 \%$ and thus may help exclude $\mathrm{IA}^{[9,24]}$. For LFA in a retrospective study of sputum and BAL samples, cross-reactivity with Scedosporium spp., Fusarium spp., Saccharomyces cerevisiae, Candida parapsilosis, and Geotrichium spp. has been described ${ }^{[20]}$.

In our study LFA detected $86.7 \%$ of samples that were positive with GM ELISA. LFA has similar positivity in BAL and serum samples ( 88.0 vs. $85.0 \%$ ) when samples previously positive by GM ELISA were tested. While in BAL samples low intensity test line of $1+$ was significantly more frequent in GM ELISA positive samples with ODI $<1.0$ than with ODI $\geq 1.0$, with serum samples that was not the case. Observation noticed in our study were low intensity test lines $(1+)$ that were found even in serum samples with high ODI $(>4.0)$. This could be explained by potentially interfering substances found in the serum samples although heating to $120^{\circ} \mathrm{C}$ is included in LFA protocol to denature the immunoglobulins and any other potentially interfering proteins. Another explanation could be the 
visual readout of the test line that may be influenced by the individual interpretation of the test line, especially for weak positive test results that were mentioned in previous studies ${ }^{[21]}$. An automated readout with quantitative results reporting GM index and manufacturer's recommended positivity threshold $(\mathrm{GMI} \geq 0.5)$ is now available which could circumvent this drawback ${ }^{[14,21,23]}$.

We are aware of different cut-off levels for GM ELISA ODI suggested by guidelines from different medical societies that should be used when BAL samples are tested. According to ESCMID-ECMM-ERS guidelines ODI of 0.5-1.0 has decreased predictive values compared to results of $>1.0$ which is the cut-off usually used in our hospital when the ELISA GM result is interpreted in the clinical context ${ }^{[13]}$. On the other hand, EORTC/MSGERC guidelines consider ODI $>0.8$ in BAL significant ${ }^{[25]}$. In our study, when comparing two methods, we used only the cut-off level from manufacturer's instructions according to which samples with ODI $\geq 0.5$ were considered positive. If cut-off level for GM ELISA BAL positivity of $>1.0$ was used, LFA would have higher positivity rate of $93.75 \%(15 / 16)$ in ELISA GM BAL positive samples in comparison to $88.0 \%(22 / 25)$ observed when BAL samples with ODI $>0.5$ were tested. Furthermore, if cut-off level for GM ELISA BAL positivity of $>1.0$ was used, the visual readout and subjective interpretation of LFA on BAL samples would be less important critical factor since our study showed that low intensity test line of $1+$ was significantly more frequent in GM ELISA positive BAL samples with ODI $<1.0$.

\section{Conclusion}

Preliminary results of LFA evaluation in our study are in accordance with the literature data and support the fact that results obtained with this test are comparable to GM ELISA and serve as useful tool in IA diagnostics. To our knowledge this is the first study comparing LFA semiquantitative results in a form of test line intensity with ODI obtained with GM ELISA in the same sample. Since low intensity lines $(1+)$ were found even in serum samples with high ODI, this potentially makes BAL a superior sample when it comes to galactomannan detection with LFA, at least when visual and not automated reading is done. The advantages of this test are its promptness, simplicity and the ability to test individual samples. Although the visual readout of the test line may be influenced by the individual interpretation, an automated readout with quantitative results is available now. The major gain over ELISA method is that GM detection becomes accessible to smaller laboratories with limited number of samples since it is not necessary to collect sufficient number of samples for testing to be cost effective.

Establishing diagnosis is still complex, time consuming and multidisciplinary approach is oftentimes required. Each patient must be assessed individually based on combination of clinical data, radiological evidence and microbiology findings. Fortunately, progress in the field of mycology regarding GM detection has demonstrated promising results obtained by commercially available immunochromatographic assays.

Funding: Nothing to declare

\section{Conflict of interest: Nothing to declare}

\section{REFERENCES}

${ }^{[1]}$ Schmiedel Y, Zimmerli S. Common invasive fungal diseases: an overview of invasive candidiasis, aspergillosis, cryptococcosis, and Pneumocystis pneumonia. Swiss Med Wkly. 2016;146:w14281.

${ }^{[2]}$ Darling BA, Milder EA. Invasive Aspergillosis. Pediatr Rev. 2018;39(9):476-8.

${ }^{[3]}$ Moura S, Cerqueira L, Almeida A. Invasive pulmonary aspergillosis: current diagnostic methodologies and a new molecular approach. Eur J Clin Microbiol Infect Dis. 2018;37(8):13931403.

${ }^{[4]}$ Bongomin F, Gago S, Oladele RO, Denning DW. Global and Multi-National Prevalence of Fungal Diseases-Estimate Precision. J Fungi (Basel). 2017; 3(4): 57.

${ }^{[5]}$ Barton RC. Laboratory diagnosis of invasive aspergillosis: from diagnosis to prediction of outcome. Scientifica (Cairo). 2013;2013:459405.

${ }^{[6]}$ Lass-Flörl C. How to make a fast diagnosis in invasive aspergillosis. Med Mycol. 2019;57(Suppl 2):S155-S160.

[7] Tudesq JJ, Peyrony O, Lemiale V, Azoulay E. Invasive Pulmonary Aspergillosis in Nonimmunocompromised Hosts. Semin Respir Crit Care Med. 2019;40(4):540-7.

${ }^{[8]}$ Cadena J, Thompson GR 3rd, Patterson TF. Invasive Aspergillosis: Current Strategies for Diagnosis and Management. Infect Dis Clin North Am. 2016;30(1):125-42.

${ }^{[9]}$ Ostrosky-Zeichner L, Al-Obaidi M. Invasive Fungal Infections in the Intensive Care Unit. Infect Dis Clin North Am. 2017;31(3):475-87.

${ }^{[10]}$ Koehler P, Bassetti M, Chakrabarti A, et al. Defining and managing COVID-19-associated pulmonary aspergillosis: the 2020 ECMM/ISHAM consensus criteria for research and clinical guidance. Lancet Infect Dis. 2021;21(6):e149-e162.

${ }^{[11]}$ Verweij PE, Rijnders BJA, Brüggemann RJM, et al. Review of influenza-associated pulmonary aspergillosis in ICU patients and proposal for a case definition: an expert opinion. Intensive Care Med. 2020;46(8):1524-35.

${ }^{[12]}$ Salmanton-García J, Sprute R, Stemler J, et al. COVID-19-Associated Pulmonary Aspergillosis, March-August 2020. Emerg Infect Dis. 2021;27(4):1077-86.

${ }^{[13]}$ Ullmann AJ, Aguado JM, Arikan-Akdagli S, et al. Diagnosis and management of Aspergillus diseases: executive summary of the 2017 ESCMID-ECMM-ERS guideline. Clin Microbiol Infect. 2018;24:e1-e38. 
${ }^{[14]}$ Jenks JD, Miceli MH, Prattes J, Mercier T, Hoenigl M. The Aspergillus Lateral Flow Assay for the Diagnosis of Invasive Aspergillosis: an Update. Curr Fung Infect Rep. 2020; Dec 4:1-6.

${ }^{[15]}$ Chabi ML, Goracci A, Roche N, Paugam A, Lupo A, Revel MP. Pulmonary aspergillosis. Diagn Interv Imaging. 2015; 96(5): 435-42.

${ }^{[16]}$ Boch T, Buchheidt D, Spiess B, Miethke T, Hofmann WK, Reinwald M. Direct comparison of galactomannan performance in concurrent serum and bronchoalveolar lavage samples in immunocompromised patients at risk for invasive pulmonary aspergillosis. Mycoses. 2016;59(2):80-5.

${ }^{[17]}$ Danion F, Rouzaud C, Duréault A, et al. Why are so many cases of invasive aspergillosis missed? Med Mycol. 2019;57(Suppl 2):S94-S103.

${ }^{[18]}$ D'Haese J, Theunissen K, Vermeulen E, et al. Detection of Galactomannan in Bronchoalveolar Lavage Fluid Samples of Patients at Risk for Invasive Pulmonary Aspergillosis: Analytical and Clinical Validity. J Clin Microbiol. 2012; 50(4):1258-63.

${ }^{[19]}$ Gupta A, Capoor MR, Shende T, et al. Comparative evaluation of galactomannan test with bronchoalveolar lavage and serum for the diagnosis of invasive aspergillosis in patients with hematological malignancies. J Lab Physician. 2017;9(4):234-8.

${ }^{[20]}$ Lass-Flörl C, Lo Cascio G, Nucci M, et al. Respiratory specimens and the diagnostic accuracy of Aspergillus lateral flow assays (LFA-IMMY ${ }^{\mathrm{m}}$ ): real-life data from a multicentre study. Clin Microbiol Infect. 2019; 25:1563.e1-1563.e3.

${ }^{[21]}$ Mercier T, Dunbar A, de Kort E, et al. Lateral flow assays for diagnosing invasive pulmonary aspergillosis in adult hematology patients: A comparative multicenter study. Med Mycol. 2020;58(4):444-52.

${ }^{[22]}$ Jenks JD, Mehta SR, Taplitz R, Law N, Reed SL, Hoenigl M. Bronchoalveolar lavage Aspergillus Galactomannan lateral flow assay versus Aspergillus-specific lateral flow device test for diagnosis of invasive pulmonary Aspergillosis in patients with hematological malignancies. J Infect. 2019;78(3):249-59.

${ }^{[23]}$ White PL, Price JS, Posso R, Cutlan-Vaughan M, Vale L, Backxa M. Evaluation of the Performance of the IMMY sona Aspergillus Galactomannan Lateral Flow Assay When Testing Serum To Aid in Diagnosis of Invasive Aspergillosis. J Clin Microbiol. 2020;58: e00053-20.

${ }^{[24]}$ Ruhnke M, Behre G, Buchheidt D, et al. Diagnosis of invasive fungal diseases in haematology and oncology: 2018 update of the recommendations of the infectious diseases working party of the German society for hematology and medical oncology (AGIHO). Mycoses. 2018;61(11):796-813.

${ }^{[25]}$ Bassetti M, Azoulay E, Kullberg BJ, et al. EORTC/MSGERC definitions of invasive fungal diseases: summary of activities of the intensive care unit working group. Clin Infect Dis. 2021;72:121-7. 